\title{
Paleogeneticist view of leather: The role of mitochondrial DNA to uncover the mysteries of fake leather and its products
}

\author{
Rachel Matar ${ }^{1}$ and Maxime Merheb ${ }^{1, *}$ \\ ${ }^{1}$ Department of Biotechnology, American University of Ras Al Khaimah AURAK, Ras Al Khaimah, P.O Box \\ 10021, United Arab Emirates
}

\begin{abstract}
Currently, Leather-based products are manufactured in abundance, but the fact is; most of these products are manufactured using fake materials which cause a major fraud issue in the market. The extravagance of leather trade led to the extinction of numerous species. Almost 33\% of exotic leather comes from endangered species. This trade is shrewdly disguised under the "Fur" industry. With the ability to extract and analyze DNA from ancient substance, molecular species identification methods have been recently developed, including the use of DNA amplification using PCR and derived methods of molecular biology. At a deeper perspective, degraded DNA identification has gained significant advances in the field of criminalistics, forensic science, as well as fraud detection and quality control in food. This study will illustrate the objectives of identifying species origin of leather either for frauds identification and endangered species protection as well. We are presenting also a general assessment of the chemical degradations of DNA that can be extracted from manufactured leather. During tanning process, the rehydration of the skin in warm acid solution promotes the DNA hydrolysis. Rehydration is followed by immersion of the skin in the lime water which induces the DNA oxidation. Finally, adding tannins which are polyphenols known for their inhibitory effect on PCR, will significantly decrease the chance of DNA amplification. In conclusion, one can make an analogy between all these leather processing conditions and the conditions affecting a fossil in its burial environment, therefore, it is essential that the DNA of leather must be considered and analyzed as ancient DNA.
\end{abstract}

KEY WORDS: MITOCHONDRIAL DNA; PALEOGENETICS; LEATHER; FORENSIC DNA; BIODIVERSITY

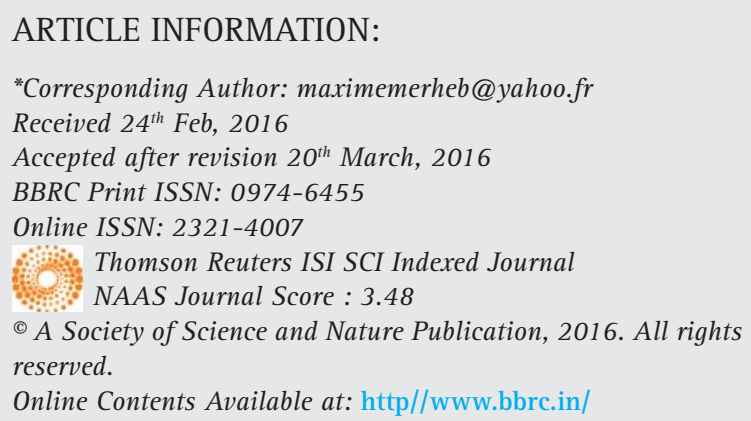


Molecular identification of species origin of leather would be particularly important, either concerning the commercial or other fundamental aspects. On the commercial aspect, leather manufactured products are very common and serious fraud situations exists due to the difficulty to recognize the species origin after the manufacturing process, and the value of products from different species may vary. In addition, a certain number of endangered protected wildlife species are fraudulently used in the leather market (Merheb et al., 2015) therefore; molecular recognition of the species present in these substrates has an important impact in terms of protecting biodiversity. For this purpose, institutions are already promoting the development of detection methods for DNA testing of products related to leather. This study is presenting a general assessment of the chemical degradations of DNA extracted from manufactured leather concluding that due to the degradation that occurs during the tanning process, only mtDNA can be expected to survive.

\section{INTRODUCTION}

Nowadays, species identification is a critical issue to ensure and protect biodiversity and detect fraud in commercial food (Lefrançois et al., 1997, Lockley and Bardsley, 2000, Woolfe and Primrose, 2004, Merheb et al., 2015). The demand for species identification has increased due to the various food crises that occurred in the past 10 years (Bovine spongiform encephalopathy BSE, Foot-and-mouth disease FMD, avian flu, swine flu (Hoffmann et al., Eloit et al., 2005, Vassioukovitch et al., 2005, Wan et al., 2005, Mafra et al., 2008, Nicholson et al., 2008)). A significant loss in biodiversity is caused by endangered species as at least ten to twenty percent of the entire plants and vertebrate species are at the risk of extinction in the coming decades (UICN http://www.redlist.org and CITES http:// www.cites.org) (Teletchea et al., 2005). Wildlife species are ranked third in the world for the largest amount of smuggling and poaching after drugs and weapons, which are considered the most serious threat to the survival of the animal kingdom (Manel et al., 2002, Manel et al., 2005, Teletchea et al., 2005).

Each year, millions of animals are endangered by unlawful killing, captured for hunting games, collected for private zoos, decorative items (Elephant Ivory Comstock et al., 2003), traditional medicine (The Tiger Wan and Fang, 2003, Wetton et al., 2004), Rhino (Hsieh et al., 2003), and human consumption (Sea Turtles and their eggs Moore et al., 2003). Therefore; identifying the species presented in the organic substrates (Fresh, Processed and Ancient) by reliable and quick methods is a matter of urgency. The case of traceability in food is often cited yet the application may also affect many other areas which should be considered. The range of substrates in which species are determined is very broad. It varies from a simple case such as a species found in a pure state in a fresh substrate to a complete situation of species found as mixtures and where product had been significantly altered (Teletchea et al., 2005).

Different species identification methods for processed organic products have been developed such as morphological studies (Nunez, 1951, Tsuganezawa, 1965, Prayson et al., 2008), protein analysis (Ashworth, 1987) and chemical analysis (Guy et al., 2000, Ozaki et al., 2004), yet these methods are outdated, as it is not very effective for the analysis of products which have been significantly altered (Teletchea et al., 2005, Merheb et al., 2016).

On the other hand, Molecular identification methods have been recently developed, including the use of DNA amplification using PCR and derived methods of molecular biology (Goussé-Donne et al., 2001). With the ability to extract and analyze DNA from ancient substance, when palaeogenetics took off, there were a couple of decades where it allowed access to the genomes of species or extinct populations (Golenberg, 1991, Cano and Poinar, 1993, Cano et al., 1994, Lindahl, 2000, Teletchea et al., 2005, Merheb et al., 2015). At a deeper perspective, degraded DNA identification has gained significant advances in the field of criminalistics (Leonard et al., 2007) and forensic science (Capelli et al., 2003), as well as fraud detection and quality control in food (GousséDonne, 2001, Teletchea et al., 2005).

DNA is a stable molecule, a very small amount is sufficient enough to undergo a complete analysis, which allows the study of highly degraded substrates possible (Paabo et al., 1989, Hänni et al., 1994, Paabo et al., 2004, Feuillie et al., 2011a, Feuillie et al., 2011b). Some specific substrates such as feces and hair are now important sources for genetic analyzes (Fabbri et al., 2007). Processed products such as leather, fur and all manufactured products made from animal hides are currently very reluctant to obtain reliable results in molecular traceability.

\section{OBJECTIVES OF IDENTIFYING SPECIES ORIGIN OF LEATHER}

\section{FRAUD PREVENTION}

Leather-based manufactured products are very common and are a major fraud in the market due to the difficulty of recognizing species morphologically and because the products from different species do not have the same commercial value. On the labels of most clothes made of leather in the South East Asian countries (such as coats, hats, handbags, gloves, shoes, toys, decorations) we find 
the misleading tag 'leather' or 'real fur'. This is often a false description which induces, to a large extent, the consumer astray. To promote their sales, clothing accessories and fur from cats or dogs are labeled under other names. For example, fur traders explained to investigators that labeling depended on the preferences of the buyer! Thus, we find the cat fur sold under the names "Lippi Cat", "China Cat" or "Rabbit". As for the dog fur, we find it under the fanciful name of "Asian Wolf" or "Chinese dog" etc. On 13 November 2008, the customs office of Villepinte announced a seize operation in a Paris warehouse of 4034 vests, jackets and coats with fur collars, declared as fake fur, but the inspections revealed that the fur came from dogs and cats. The National Museum of Natural History has confirmed the presence of raccoon dog fur among the documents seized, (www. douane.gouv.fr). This trade is not limited to Asia: Fur is used worldwide. In 1997, Deux-Sèvres, 1500 skins of cats, for the manufacture of toys, were discovered by the Department of Veterinary Services. The introduction, importation and marketing of raw hides or treated products derived from dogs and cats are prohibited in France by an order released on the 13th of January 2006. These provisions were supplemented by Community provisions in Indeed, the European Union adopted Regulation EC No 1523/2007 on the 11th of December 2007, which aims to ensure the protection of animals by banning the trade, including the import and export of cat or dog fur. Since the introduction of these new regulations, institutions are trying to develop detection methods for DNA testing of products containing leather imitation.

\section{PROTECTION OF BIODIVERSITY}

Biodiversity is currently experiencing a major crisis, both in terms of numbers and the rate of population or species extinctions (Fonseca and Benson, 2003, DeSalle and Amato, 2004). Thus, since the seventeenth century, more than 250 species of birds, mammals, reptiles and amphibians were made extinct in the world because of human activities (Fonseca and Benson, 2003). The real crisis is in most cases extinction was the direct result of hunting, fishing, overfishing, poaching, and indirectly by the loss or damage of habitats, degradation of the natural environment: pollution, introduction of other species or other human activities (Leakey and Lewin, 1995). We realized in recent years that trading (legally and illegally) of species, including those endangered species has contributed a severe threat to global biodiversity. The wildlife trade and their products also represent the third largest trade after drugs and weapons (Manel et al., 2002). The luxury leather trade has pushed many species to extinction (www.endangeredspecieshandbook. org). Nearly a third of exotic leathers come from endan- gered species, with impunity poached (snakes, lizards, crooked, crocodiles, ostriches, tigers, leopards, zebras, opossums, elephants, sharks, seals, walruses). This trade is cleverly concealed by the fur industry.

In Parallel, nongovernmental organizations also play a vital role in control of international trade of wild species by influencing decision makers with the help of their international conferences (Ringuet, 2004). Among these actions we cite the program TRAFFIC (www.traffic.org), created in 1976 by IUCN (International Union for Conservation of Nature), (http://www.iucn.org) and the WWF (World Wild Fund). Currently, this international network coordinated by TRAFFIC has collaborators in more than 22 countries and projects in more than 10 countries. The famous "Red list" (http://www.iucnredlist.org) of the IUCN is estimating that more than 23,000 species are endangered as of 2015. Numbers of threatened species are listed by major groups of organisms since 1996.

\section{LEATHER MANUFACTURING PROCESSES FROM ANIMAL SKINS}

For thousands of years, humans have started to convert animal hides into resistant products which nowadays are referred to as "Leather". The remains attributed to leather work are rare on prehistoric sites. However remnants related to this activity, as the OUI2 site in Siberia dated between 22,000 and 17,000 BP are exceptional (Vasil'ev, 1990 , Vasil'ev, 1994). A set of 21 ribs of sheep have been identified in the site. The ribs are introduced vertically into the ground forming an oval of $1.50 \mathrm{~m}$ of $0,85 \mathrm{~m}$. This set of rods has been interpreted as a tension structure of hides during the drying process (Beyries, 2008).

Nowadays, the manufacturing of leather mainly consists of salting, desalting and tanning. Salting is designed to remove water from the tissues to slow the development of microorganisms and stop the putrefaction action. After 15 days, the skins are desalted; they are examined one by one and organized according to their thickness, weight or surface. The procedure of changing the skin into leather is called Tanning. This process is accomplished by tannins which are a variety of chemicals, the most well-known used chemicals today are mineral or vegetable (Sharphouse, 1983). Tannins transform raw hides from a putrescible, sensitive and hydrated material to imputrescible, impermeable, abrasion resistant, and solid material, referred to as "Leather".

\section{FROM PALEOGENETICS TO FORENSIC DNA}

For over 25 years, many paleogenetic studies have shown that the DNA molecule remains very stable after the death of organisms, despite the time and environmental effects 
(Higuchi et al., 1984). Since 1984, the first publication in this area was released (isolation of a few hundred base pairs of a mitochondrial gene from a tissue of a taxidermied specimen, the quagga, died over a hundred and forty years ago (Higuchi et al., 1984)), numerous studies have shown that it is possible to retrieve and analyze a much older samples of DNA (Hänni et al., 1994, Loreille et al., 2001, Orlando et al., 2002, Poinar, 2002, Orlando et al., 2003, Salamon et al., 2005, Teletchea et al., 2005) such as samples of cave bear Ursus spelaeus dating back to 35,000 years ago (Hänni et al., 1994) and samples of woolly rhinoceros dating back to 60000 years ago (Orlando et al., 2003). Hence the idea, by analogy, to use the stable and resistant DNA molecule, to identify species in processed or degraded products whilst undergone many chemical and physical treatments (Bartlett and Davidson, 1992, Ozaki et al., 1998, Etienne et al., 1999, Aguado et al., 2001, Hold et al., 2001, Urdiain et al., 2004, Teletchea et al., 2005, Lucey, 2006, Lema and Burachik, 2009, Botti and Giuffra, 2010). Moreover, even if the DNA molecule is degraded in this type of substrates (manufacturing processes, canning, smoking etc.) remains always possible to amplify it using Polymerase Chain Reaction (PCR) (Mullis and Faloona, 1987, Saiki et al., 1988, Saiki et al., 1985) small fragments of DNA with sufficient information to discriminate between closely related species (Kocher et al., 1989). Fur- thermore, since the DNA is present in all cells, it is potentially possible to identify a species from any type of substrate. However, the DNA molecule modified or degraded in these products has several characteristics that must be taken into consideration when developing new methods.

\section{DNA CHARACTERISTICS IN LEATHER: A PROCESSED PRODUCT}

The ancient DNA goes through several types of inflicting damage and changes that begins shortly after the death of the animal, especially the fragmentation of DNA into very small pieces and creation abasic sites, so-called post-mortem degradations (Paabo et al., 2004). The different processing methods will cause breaks in the DNA molecule. Thus, molecular identification from such samples must be based on the analysis of small fragments generally between 100-150 base pairs. Figure 1 summarizes these treatments.

The DNA molecule in this type of substrates are not only broken and deteriorated, but also present in very small quantities (Poinar, 2002, Hänni et al., 1994, Loreille et al., 2001), which further reduces the number of DNA fragments with a size sufficient enough for analysis (Teletchea, 2005). Therefore the paleogenetic studies and also non-invasive ecology that is to say the study of popula-

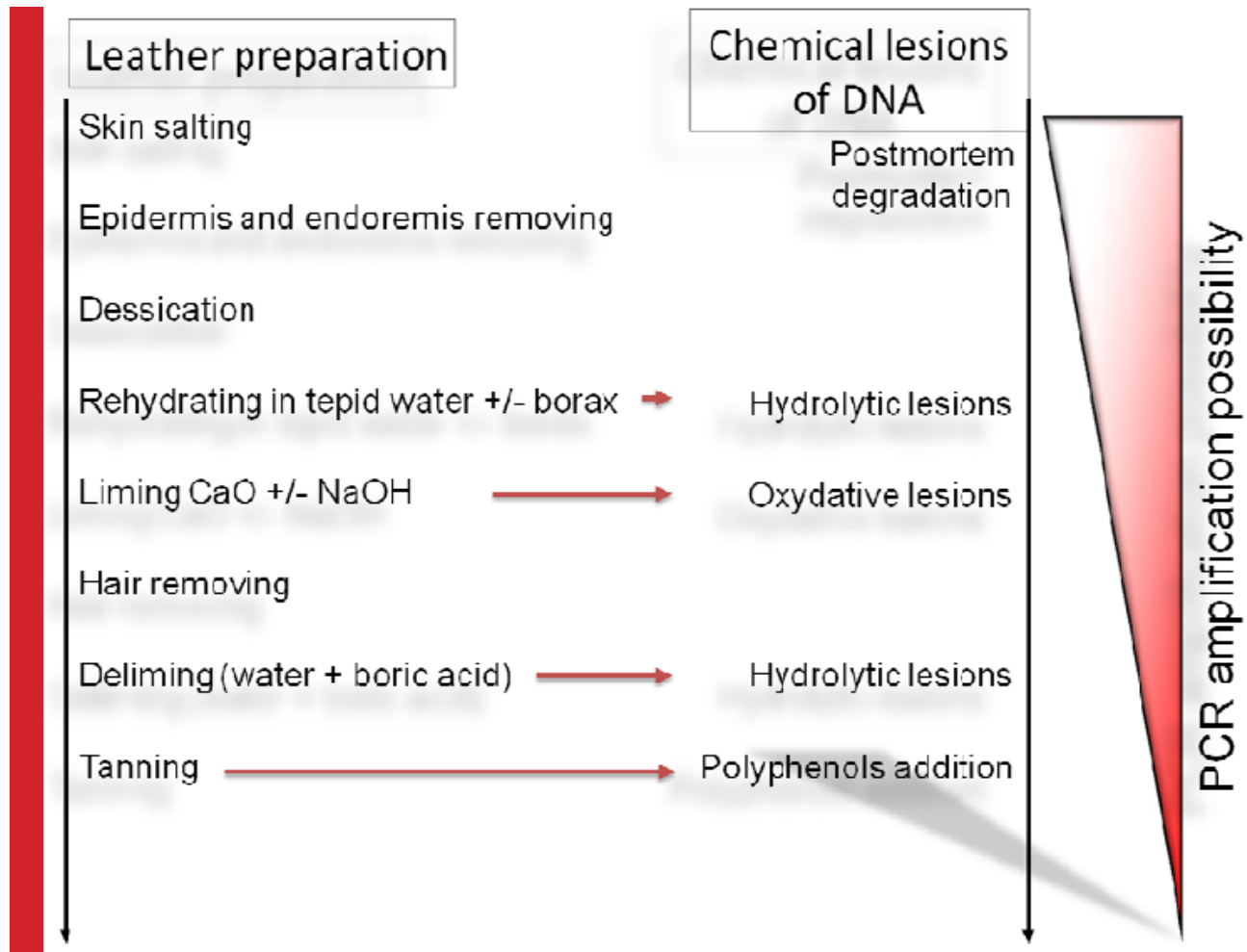

FIGURE 1: The various stages of preparation of the leather and consequences in terms of chemical lesions. 
tions or species from samples collected in the field and hairs (Fabbri et al., 2007, Debruyne et al., 2008, Schwarz et al., 2009), and feces (Taberlet and Bouvet, 1992), etc. showed that it was often necessary to increase the number of PCR cycles (up to 55 or 60 cycles) to have sufficient DNA to allow subsequent analyzes (Merheb et al., 2016).

Given $i$ ) the nature of degraded DNA in such samples and $i$ i) the fact that the PCR is an extremely sensitive method, it is possible that a single intact exogenous DNA molecule can be preferentially amplified instead of the degraded endogenous molecule (Merheb et al., 2016). Therefore, the samples must be handled (prior to PCR) in dedicated laboratories (physically isolated) (Loreille et al., 2001). In addition, it is essential to add "carrier effect" control (Cooper, 1992, Handt et al., 1994), which amplifies degraded DNA extracted from another species. The role of this control is to help trace amplified exogenous contaminant DNA, in the presence of ancient DNA.

Many factors from various sources are co-extracted with the target DNA and may inhibit PCR (Cooper, 1992, Wilson, 1997, Shutler et al., 1999, Merheb et al., 2015, Merheb et al., 2014, Feuillie et al., 2011c, Feuillie et al., 2014). Therefore, the absence of amplification may be related to inhibition of the PCR, rather than an insufficient amount or absence of target DNA.

At the amplification, the inhibitors can be directly neutralized by using BSA (Bovine Serum Albumin) to PCR reagents (Hagelberg et al., 1989, Hänni et al., 1994, Merheb, 2010). Indeed these proteins trap, by electro- static interactions, a variety of inhibitors of Taq polymerase (Pääbo, 1989).

Chemical modifications are probably the less known characteristics of the DNA in the processed products, but paleogenetic and noninvasive ecology studies have shown that the environment (acidity, UV, humidity, etc.) could, in fact, induce chemical changes (oxidation or hydrolysis) of the DNA (Pääbo, 1989, Paabo et al., 1989, Hoss et al., 1996). In this case, the nucleic acids have modifications or artefactual mutations, which are changes in the nature of the nucleotide bases (Poinar, 2002). During PCR amplification, the Taq polymerase will mistakenly pair these modified bases.

Thus, opposite to the 8hydroxy-Guanine, oxidation product of Guanines, Taq will associate an adenine (A) and not cytosine (C) (Lindahl et al., 1993, Feuillie et al., 2012). Once amplified, these molecules will present artifactual substitution type: C to A (Figure. 2). Similarly, the deamination of cytosine by hydrolysis forms a uracil, opposite to which an adenine is paired. This will result in the artefactual substitution type $\mathrm{C}$ to $\mathrm{T}$ and $\mathrm{G}$ to A (Figure. 2) (Hofreiter et al., 2001). Finally, Hypoxanthine is formed due to deamination by hydrolysis of adenine. Hypoxanthine preferentially associates with cytosine, which leads to the artifactual substitution type A to C (Gilbert et al., 2003a, Gilbert et al., 2003b).

A. The deamination of cytosine by hydrolysis forms Uracil.

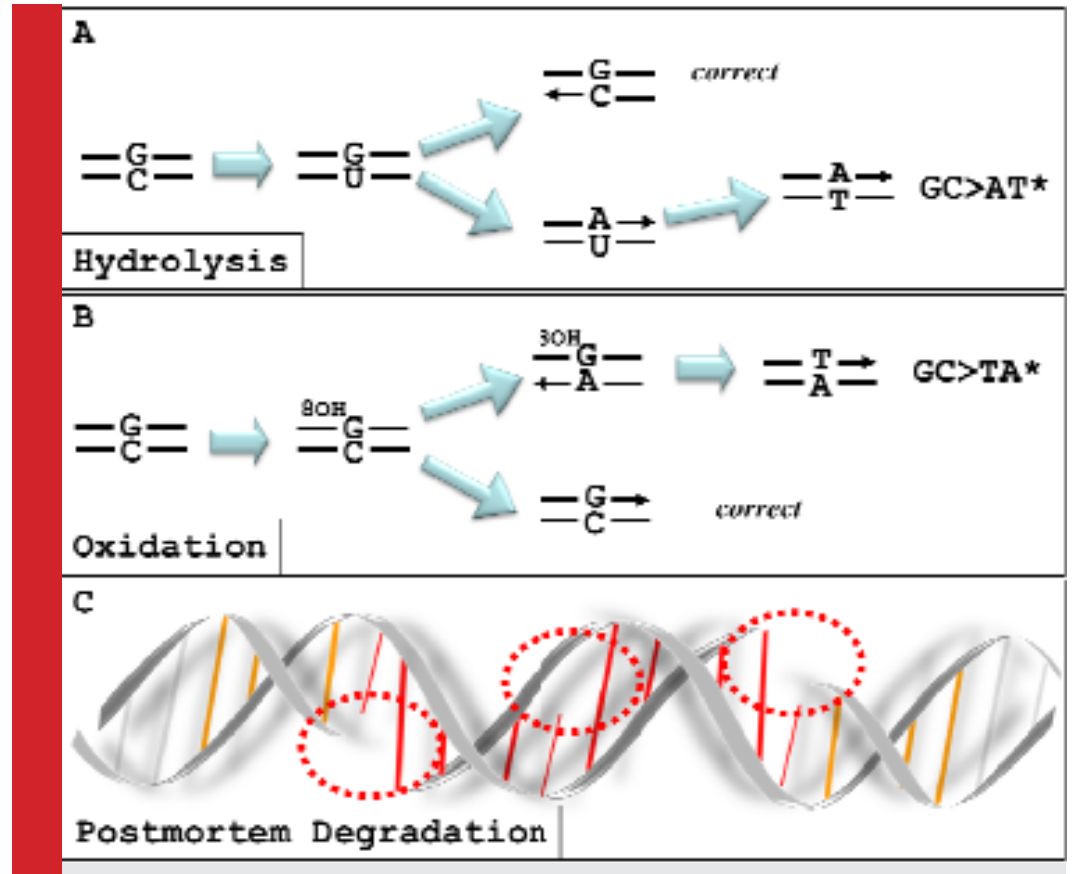

FIGURE 2: The main consequences on PCR amplification of chemically modified DNA. 
B. 80HG: 8hydroxy-guanine, a product of guanine oxidation.

C. Post-mortem degradations: fragmentation, strands breaks, and abasic sites. The latter lesion is obtained by hydrolysis.

After drying, the skin undergoes two critical steps i) rehydration in warm water that contains boric acid (H3BO3) which promotes the hydrolysis of DNA. The hydrolysis promotes the two artifactual substitutions $\mathrm{C}$ to $\mathrm{T}$ and $\mathrm{G}$ to $\mathrm{A}$ and the creation of abasic sites which stop the elongation step of the Taq polymerase during the PCR ii) liming, immersion of the skin in the lime water $(\mathrm{CaO}+$ $\mathrm{NaOH}$ ), which promotes the oxidation of DNA that promotes the artifactual substitution $\mathrm{G}$ to $\mathrm{T}$ and $\mathrm{C}$ to $\mathrm{A}$. The final step of tanning consists of adding tannins which are polyphenols known for their inhibitory effect on PCR. In conclusion, one can make an analogy between all these leather processing conditions and the conditions affecting a fossil in its burial environment. For all mentioned reasons, it is essential that the DNA of leather must be considered and analyzed as ancient DNA.

\section{FORENSIC DNA TECHNIQUES TO IDENTIFY SPECIES ORIGIN OF LEATHER}

In a recent study, authors have focused on optimizing an ideal DNA extraction method for leathers (Merheb et al., 2014). Thus, $200 \mathrm{mg}$ of modern chamois leather sample were extracted by the most used DNA extraction methods for degraded DNA, Phenol-Chloroform, and Silica. The final extracted volume for both was $100 \mu \mathrm{l}$. Specific PCR mix contained an increased volume of chamois extract (0,25-2 $\mathrm{ll})$. With Phenol-chloroform extraction method, the extract was colored, therefore, authors were obliged to perform extract purification using Minelute Purification Kit (Qiagen ${ }^{\circledR}$ ) and Chicken Serum Albumin which were added to the PCR mix. Authors have obtained amplifications only for 0,25 and $0,5 \mu l$ of extract. With the Silicamodified method, the extract was colorless. Thus, without any further purification or adding animal serum in PCR tubes, authors obtained amplifications for all volumes of extract. These results have suggested the Silica-modified as non-inhibitive DNA extraction method for species identification in Leather. Authors concluded that the critical condition of silica extraction method is that the $\mathrm{pH}$ must be monitored during the entire process and in every step. Otherwise, DNA is released during washing steps or shall remain linked to silica particles after elution.

\section{CONCLUSION}

Through an interesting study by Vuissoz et al. it was proven that "nuDNA" cannot be amplified from leather, due to the degradation that occurs during the tanning process. Immersion of the skin into liquids that are either acidic or basic occurs in many of the steps of the tanning process. Rates of DNA degradation increases quickly as $\mathrm{pH}$ varies from neutral (Lindahl et al., 1993) in solutions, such steps are expected to prompt the degradation of the DNA. Furthermore, Polyphenols have the ability to promptly cross-link proteins (for instance collagen) (Vuissoz et al., 2007), this is the premise in respect to why skins are tanned with polyphenols. Such cross-linking may also influence the DNA leather various ways that are unsafe to PCR amplification. The DNA molecules might become unamplifiable by PCR if they directly crosslink the proteins. Then again, if an imperative part of the harmful procedure is the cross-linking of DNA to collagen or other proteins, basic explanations might be either that the mtDNA molecules came into contact with fewer portion of proteins preceding the tanning process (nuDNA is complexed with various packing proteins such as histones), or that again the mitochondrion layer essentially isolates and shields the mtDNA from different proteins inside of the cell (Vuissoz et al., 2007). However, with other aDNA studies, the observation might likewise basically be an impact of the extraordinarily elevated duplicate number of the mitochondrial genomes concerning nuclear genomes which convey a numerical advantage. nuDNA was not focused upon in recent studies with deals with ancient and modern leathers, as to what extent mtDNA can be expected to survive remains an open question. Due to silica-based DNA extraction method and a battery of ultra-specific primers, Merheb et al. 2016 were able to amplify mtDNA from the ancient and modern leathers and were clearly able to identify species origin of that interesting tissue (Merheb et al., 2016).

The extracted DNA is degraded and chemically altered during the process of leather manufacturing, therefore; utilizing tannins will enable the co-extraction of DNA with significant amounts of inhibitors (Vuissoz et al., 2007). While animal sera could be able to solve the problem of inhibition, previous studies have reported the presence of animal DNA in PCR reagents (Champlot et al., Leonard et al., 2007). Minimizing the use of animal origin PCR reagents would be greatly preferred, in particular for the BSA which directly comes from beef, one of the most likely candidates for the production of leather (Merheb et al., 2016). The animal kingdom species are decreasing drastically over the past period of time and it is proven that he luxury leather trade has pushed many species to extinction. In order to preserve biodiversity, develop fraud detection in leather and commercial-food, the research in species identification methods and techniques must continue and prosper and a focus mitochondrial DNA would be of great importance as the only key to identify species origin in leather. 


\section{REFERENCES}

Aguado, V., Vitas, A. I. \& Garcia-Jalon, I. (2001). Random amplified polymorphic DNA typing applied to the study of cross-contamination by Listeria monocytogenes in processed food products J Food Prot Vol. 64 Issue 5: 716-720.

Ashworth, R. B. (1987). Amino acid analysis for meat protein evaluation J Assoc Off Anal Chem Vol. 70 Issue 1: 80-85.

Bartlett, S. E. \&t Davidson, W. S. (1992). FINS (forensically informative nucleotide sequencing): A procedure for identifying the animal origin of biological specimens Biotechniques Vol. 13 Issue 4: 518.

Beyries, S. (2008). Modélisation du travail du cuir en ethnologie : proposition d'un système ouvert à l'archéologie Anthropozoologica Vol. 43. Issue 1: 9-42.

Botti, S. \& Giuffra, E. (2010). Oligonucleotide indexing of DNA barcodes: identification of tuna and other scombrid species in food products BMC Biotechnol Vol. 10 Issue: 60.

Cano, R. J., Borucki, M. K., Higby-Schweitzer, M., Poinar, H. N., Poinar, G. O., Jr. \& Pollard, K. J. (1994). Bacillus DNA in fossil bees: an ancient symbiosis? Appl Environ Microbiol Vol. 60 Issue 6: 2164-2167.

Cano, R. J. \& Poinar, H. N. (1993). Rapid isolation of DNA from fossil and museum specimens suitable for PCR Biotechniques Vol. 15 Issue 3: 432-434, 436.

Capelli, C., Tschentscher, F. \& Pascali, V. L. (2003). Ancient protocols for the crime scene? Similarities and differences between forensic genetics and ancient DNA analysis Forensic Sci Int Vol. 131 Issue 1: 59-64.

Champlot, S., Berthelot, C., Pruvost, M., Bennett, E. A., Grange, T. \& Geigl, E. M. An efficient multistrategy DNA decontamination procedure of PCR reagents for hypersensitive PCR applications PLoS One Vol. 5 Issue 9:

Comstock, K. E., Ostrander, E. A. \&t Wasser, S. K. (2003). Amplifying Nuclear and Mitochondrial DNA from African Elephant Ivory: a Tool for Monitoring the Ivory Trade Conservation Biology Vol. 17 Issue 6: 1840-1843.

Cooper, A. (1992). Removal of colourings, inhibitors of PCR, and the carrier effect of PCR contamination from ancient DNA samples Anc. DNA Newslett. Vol. Issue 1: 31-32.

Debruyne, R., Schwarz, C. \&t Poinar, H. (2008). Comment on Whole-Genome Shotgun Sequencing of Mitochondria from Ancient Hair Shafts» Science Vol. 322 Issue 5903: 857a-.

Desalle, R. \& Amato, G. (2004). The expansion of conservation genetics Nat Rev Genet Vol. 5 Issue 9: 702-712.

Eloit, M., Adjou, K., Coulpier, M., Fontaine, J. J., Hamel, R., Lilin, T., Messiaen, S., Andreoletti, O., Baron, T., Bencsik, A., Biacabe, A. G., Beringue, V., Laude, H., Le Dur, A., Vilotte, J. L., Comoy, E., Deslys, J. P., Grassi, J., Simon, S., Lantier, F. Ct Sarradin, P. (2005). BSE agent signatures in a goat Vet Rec Vol. 156 Issue 16: 523-524.

Etienne, M., Jerome, M., Fleurence, J., Rehbein, H., Kundiger, R., Yman, I. M., Ferm, M., Craig, A., Mackie, I., Jessen, F., Smelt, A. \& Luten, J. (1999). A standardized method of iden- tification of raw and heat-processed fish by urea isoelectric focusing: a collaborative study Electrophoresis Vol. 20 Issue 10: 1923-1933.

Fabbri, E., Miquel, C., Lucchini, V., Santini, A., Caniglia, R., Duchamp, C., Weber, J. M., Lequette, B., Marucco, F., Boitani, L., Fumagalli, L., Taberlet, P. \& Randi, E. (2007). From the Apennines to the Alps: colonization genetics of the naturally expanding Italian wolf (Canis lupus) population Mol Ecol Vol. 16 Issue 8: 1661-1671.

Feuillie, Merheb, Gillet, Montagnac, Daniel \&t Hänni. Specific DNA detection by SERRS: toward older biosignatures. Origins 2011, The International Astrobiology Society and Bioastronomy, 2011a. http://www.origins2011.univ-montp2.fr/.

Feuillie, C., Merheb, M., Gillet, B., Montagnac, G., Michot, L., Daniel, I. Et Hänni, C. Adsorption of DNA on Fe-Mg rich phyllosilicates characteristics of early oceanic environments. Origins 2011, The International Astrobiology Society and Bioastronomy, 2011b. http://www.origins2011.univ-montp2.fr/.

Feuillie, C., Merheb, M. M., Gillet, B., Montagnac, G., Daniel, I. \&t Hänni, C. (2011c). A novel SERRS sandwich-hybridization assay to detect specific DNA target PloS one Vol. 6 Issue 5: e17847.

Feuillie, C., Merheb, M. M., Gillet, B., Montagnac, G., Daniel, I. \&t Hänni, C. (2014). Detection of DNA Sequences Refractory to PCR Amplification Using a Biophysical SERRS Assay (Surface Enhanced Resonant Raman Spectroscopy) PloS one Vol. 9 Issue 12: e114148.

Feuillie, C., Merheb, M. M., Gillet, B., Montagnac, G., Hänni, C. \&t Daniel, I. (2012). Enzyme-free detection and quantification of double-stranded nucleic acids Analytical and bioanalytical chemistry Vol. 404 Issue 2: 415-422.

Fonseca, G. Et Benson, P. J. (2003). Biodiversity conservation demands open access PLoS Biol Vol. 1 Issue 2: E46.

Gilbert, M. T., Hansen, A. J., Willerslev, E., Rudbeck, L., Barnes, I., Lynnerup, N. \&t Cooper, A. (2003a). Characterization of genetic miscoding lesions caused by postmortem damage Am J Hum Genet Vol. 72 Issue 1: 48-61.

Gilbert, M. T., Willerslev, E., Hansen, A. J., Barnes, I., Rudbeck, L., Lynnerup, N. \& Cooper, A. (2003b). Distribution patterns of postmortem damage in human mitochondrial DNA Am J Hum Genet Vol. 72 Issue 1: 32-47.

Golenberg, E. M. (1991). Amplification and analysis of Miocene plant fossil DNA Philos Trans R Soc Lond B Biol Sci Vol. 333 Issue 1268: 419-426; discussion 426-417.

Goussé-Donne, C. 2001. De la phylogénie moléculaire à la traçabilité des aliments. Université Claude BernardLyon I.

Guy, P. A., Gremaud, E., Richoz, J. \&t Turesky, R. J. (2000). Quantitative analysis of mutagenic heterocyclic aromatic amines in cooked meat using liquid chromatography-atmospheric pressure chemical ionisation tandem mass spectrometry J Chromatogr A Vol. 883 Issue 1-2: 89-102.

Hagelberg, E., Sykes, B. \&t Hedges, R. (1989). Ancient bone DNA amplified Nature Vol. 342 Issue 6249: 485. 
Handt, O., Hoss, M., Krings, M. \&t Paabo, S. (1994). Ancient DNA: methodological challenges Experientia Vol. 50 Issue 6: 524-529.

Hänni, C., Laudet, V., Stehelin, D. \& Taberlet, P. (1994). Tracking the origins of the cave bear (Ursus spelaeus) by mitochondrial DNA sequencing Proc Natl Acad Sci U S A Vol. 91 Issue 25: 12336-12340.

Higuchi, R., Bowman, B., Freiberger, M., Ryder, 0. A. \& Wilson, A. C. (1984). DNA sequences from the quagga, an extinct member of the horse family Nature Vol. 312 Issue 5991: 282284.

Hoffmann, B., Harder, T., Lange, E., Kalthoff, D., Reimann, I., Grund, C., Oehme, R., Vahlenkamp, T. W. \&t Beer, M. New realtime reverse transcriptase polymerase chain reactions facilitate detection and differentiation of novel A/H1N1 influenza virus in porcine and human samples Berl Munch Tierarztl Wochenschr Vol. 123 Issue 7-8: 286-292.

Hofreiter, M., Jaenicke, V., Serre, D., Haeseler Av, A. \&t Paabo, S. (2001). DNA sequences from multiple amplifications reveal artifacts induced by cytosine deamination in ancient DNA Nucleic Acids Res Vol. 29 Issue 23: 4793-4799.

Hold, G. L., Russell, V. J., Pryde, S. E., Rehbein, H., Quinteiro, J., Vidal, R., Rey-Mendez, M., Sotelo, C. G., Perez-Martin, R. I., Santos, A. T. Ct Rosa, C. (2001). Development of a DNA-based method aimed at identifying the fish species present in food products J Agric Food Chem Vol. 49 Issue 3: 1175-1179.

Hoss, M., Jaruga, P., Zastawny, T. H., Dizdaroglu, M. \& Paabo, S. (1996). DNA damage and DNA sequence retrieval from ancient tissues Nucleic Acids Research Vol. 24 Issue: 1304-1307.

Hsieh, H. M., Huang, L. H., Tsai, L. C., Kuo, Y. C., Meng, H. H., Linacre, A. \&t Lee, J. C. (2003). Species identification of rhinoceros horns using the cytochrome b gene Forensic Sci Int Vol. 136 Issue 1-3: 1-11.

Kocher, T. D., Thomas, W. K., Meyer, A., Edwards, S. V., Paabo, S., Villablanca, F. X. \&t Wilson, A. C. (1989). Dynamics of mitochondrial DNA evolution in animals: amplification and sequencing with conserved primers Proc Natl Acad Sci U S A Vol. 86 Issue 16: 6196-6200.

Leakey, R. \& Lewin, R. 1995. The Sixth Extinction: Biodiversity and its Survival London, Phoenix.

Lefrançois, C., Hänni, C. \&t Lange, M. (1997). L'ADN antifraudes Biofutur Vol. 1997 Issue 165: 27-30.

Lema, M. A. \&t Burachik, M. (2009). Safety assessment of food products from r-DNA animals Comp Immunol Microbiol Infect Dis Vol. 32 Issue 2: 163-189.

Leonard, J. A., Shanks, O., Hofreiter, M., Kreuz, E., Hodges, L., Ream, W., Wayne, R. K. \&t Fleischer, R. C. (2007). Animal DNA in PCR reagents plagues ancient DNA research Journal of Archaeological Science Vol. 34 Issue 9: 1361-1366.

Lindahl, T. (2000). Fossil DNA Curr Biol Vol. 10 Issue 17: R616.

Lindahl, T., Prigent, C., Barnes, D. E., Lehmann, A. R., Satoh, M. S., Roberts, E., Nash, R. A., Robins, P. \&t Daly, G. (1993). DNA joining in mammalian cells Cold Spring Harb Symp Quant Biol Vol. 58 Issue: 619-624.
Lockley, A. K. \&t Bardsley, R. G. (2000). Novel method for the discrimination of tuna (Thunnus thynnus) and bonito (Sarda sarda) DNA J Agric Food Chem Vol. 48 Issue 10: 4463-4468.

Loreille, O., Orlando, L., Patou-Mathis, M., Philippe, M., Taberlet, P. \& Hänni, C. (2001). Ancient DNA analysis reveals divergence of the cave bear, Ursus spelaeus, and brown bear, Ursus arctos, lineages Curr Biol Vol. 11 Issue 3: 200-203.

Lucey, C. (2006). Brief report on the United States Food and Drug Administration Blood Products Advisory Committee recommendations for management of donors and units testing positive for hepatitis B virus DNA Vox Sang Vol. 91 Issue 4: 331-335.

Mafra, I., Ferreira, I. \&t Oliveira, M. (2008). Food authentication by PCR-based methods European Food Research and Technology Vol. 227 Issue 3: 649-665.

Manel, S., Berthier, P. \&t Luikart, G. (2002). Detecting Wildlife Poaching: Identifying the Origin of Individuals with Bayesian Assignment Tests and Multilocus Genotypes Conservation Biology Vol. 16 Issue 3: 650-659.

Manel, S., Gaggiotti, O. E. \& Waples, R. S. (2005). Assignment methods: matching biological questions with appropriate techniques Trends Ecol Evol Vol. 20 Issue 3: 136-142.

Merheb, M., Vaiedelich, S., Maniguet, T. \&t Hänni, C. (2016). Mitochondrial DNA, restoring Beethovens music Mitochondrial DNA Vol. 27 Issue 1: 355-359.

Merheb, M., Vaiedelich, S., Maniguet, T. \&t Hänni, C. (2014). Molecular Species Identification in Processed Animal Hides for Biodiversity Protection Int'l Journal of Advances in Chemical Engg., Ct Biological Sciences (IJACEBS) Vol. 1 Issue 1(2014):

Merheb, M., Vaiedelich, S., Maniguet, T. \&t Hänni, C. (2015). DNA for Species Identification in Leather: Fraud detection and endangered species protection Research Journal Of Biotechnology Vol. 10 Issue 9: 65-68.

Merheb, M. (2010). Détection et identification de l'ADN dégradé: nouvelles approches moléculaires et biophysiques. Lyon, École normale supérieure (Sciences).

Moore, M. K., Bemmiss, J. A., Rice, S. M., Quattro, J. M. \& Woodley, C. M. (2003). Use of restriction fragment length polymorphisms to identify sea turtle eggs and cooked meats to species Conservation Genetics Vol. 4 Issue 1: 95-103.

Mullis, K. B. \&t Faloona, F. A. (1987). Specific synthesis of DNA in vitro via a polymerase-catalyzed chain reaction Methods Enzymol Vol. 155 Issue: 335-350.

Nicholson, E. M., Brunelle, B. W., Richt, J. A., Kehrli, M. E., Jr. Et Greenlee, J. J. (2008). Identification of a heritable polymorphism in bovine PRNP associated with genetic transmissible spongiform encephalopathy: evidence of heritable BSE PLoS One Vol. 3 Issue 8: e2912.

Nunez, O. (1951). Morphologic interpretation of rice spicule. Cienc Invest Vol. 7 Issue 5: 230-234.

Orlando, L., Bonjean, D., Bocherens, H., Thenot, A., Argant, A., Otte, M. \&t Hänni, C. (2002). Ancient DNA and the population genetics of cave bears (Ursus spelaeus) through space and time Mol Biol Evol Vol. 19 Issue 11: 1920-1933. 
Orlando, L., Leonard, J. A., Thenot, A., Laudet, V., Guerin, C. \& Hänni, C. (2003). Ancient DNA analysis reveals woolly rhino evolutionary relationships Mol Phylogenet Evol Vol. 28 Issue 3: 485-499.

Ozaki, A., Kitano, M., Itoh, N., Kuroda, K., Furusawa, N., Masuda, T. \& Yamaguchi, H. (1998). Mutagenicity and DNA-damaging activity of decomposed products of food colours under UV irradiation Food Chem Toxicol Vol. 36 Issue 9-10: 811-817.

Ozaki, A., Yamaguchi, Y., Fujita, T., Kuroda, K. \&t Endo, G. (2004). Chemical analysis and genotoxicological safety assessment of paper and paperboard used for food packaging Food Chem Toxicol Vol. 42 Issue 8: 1323-1337.

Pääbo, S. (1989). Ancient DNA: Extraction, characterization, molecular cloning, and enzymatic amplification Proc. Natl. Acad. Sci. USA Vol. 86 Issue: 1939-1943.

Paabo, S., Higuchi, R. G. \&t Wilson, A. C. (1989). Ancient DNA and the polymerase chain reaction. The emerging field of molecular archeology The Journal of Biological Chemistry Vol. 264 Issue 17: 9709-9712.

Paabo, S., Poinar, H., Serre, D., Jaenicke-Despres, V., Hebler, J., Rohland, N., Kuch, M., Krause, J., Vigilant, L. \&t Hofreiter, M. (2004). Genetic analyses from ancient DNA Annu Rev Genet Vol. 38 Issue: 645-679.

Poinar, H. N. (2002). The genetic secrets some fossils hold Acc Chem Res Vol. 35 Issue 8: 676-684.

Prayson, B. E., Mcmahon, J. T. \&t Prayson, R. A. (2008). Applying morphologic techniques to evaluate hotdogs: what is in the hotdogs we eat? Ann Diagn Pathol Vol. 12 Issue 2: 98-102.

Ringuet, S. (2004). Les ONG et le commerce international des espèces sauvages : L'exemple de TRAFFIC Bull. Soc. Zool. Fr. Vol. 129 Issue: 163-185.

Saiki, R. K., Gelfand, D. H., Stoffel, S., Scharf, S. J., Higuchi, R., Horn, G. T., Mullis, K. B. \&t Erlich, H. A. (1988). Primerdirected enzymatic amplification of DNA with a thermostable DNA polymerase Science Vol. 239 Issue 4839: 487-491.

Saiki, R. K., Scharf, S., Faloona, F., Mullis, K. B., Horn, G. T., Erlich, H. A. \& Arnheim, N. (1985). Enzymatic amplification of beta-globin genomic sequences and restriction site analysis for diagnosis of sickle cell anemia Science Vol. 230 Issue 4732: 1350-1354.

Salamon, M., Tuross, N., Arensburg, B. \&t Weiner, S. (2005). Relatively well preserved DNA is present in the crystal aggregates of fossil bones Proc Natl Acad Sci U S A Vol. 102 Issue 39: 13783-13788.

Schwarz, C., Debruyne, R., Kuch, M., Mcnally, E., Schwarcz, H., Aubrey, A. D., Bada, J. \& Poinar, H. (2009). New insights from old bones: DNA preservation and degradation in permafrost preserved mammoth remains Nucleic Acids Research Vol. 37 Issue 10: 3215-3229.

Sharphouse, J. H. 1983. Leather technician's handbook, Leather Producers' Association.

Shutler, G. G., Gagnon, P., Verret, G., Kalyn, H., Korkosh, S., Johnston, E. \&t Halverson, J. (1999). Removal of a PCR inhibi- tor and resolution of DNA STR types in mixed human-canine stains from a five year old case J Forensic Sci Vol. 44 Issue 3: 623-626.

Taberlet, P. \&t Bouvet, J. (1992). Bear conservation genetics Nature Vol. 358 Issue 6383: 197.

Teletchea, F. 2005. Révision taxonomique des Gadidae et Puce à ADN pour l'identification d'espèces: De l'intérêt de la Systématique. Universite Claude Bernard - Lyon I.

Teletchea, F., Maudet, C. \&t Hänni, C. (2005). Food and forensic molecular identification: update and challenges Trends Biotechnol Vol. 23 Issue 7: 359-366.

Tsuganezawa, 0. (1965). [Morphological studies on the ingested food. Identification of the species of the ingested fish] Nihon Hoigaku Zasshi Vol. 19 Issue 5: 363-395.

Urdiain, M., Domenech-Sanchez, A., Alberti, S., Benedi, V. J. Et Rossello, J. A. (2004). Identification of two additives, locust bean gum (E-410) and guar gum (E-412), in food products by DNA-based methods Food Addit Contam Vol. 21 Issue 7: 619625.

Vasil'ev, S. A. (1990 ). Le Paléolithique final du bassin supérieur de l'Iénisseï d'après les fouilles près du vil-lage de Maïna Anthropologie Vol. 94 Issue 4: 763-782.

Vasil'ev, S. A. (1994). Oui2 : Un site préhistorique à riche stratigraphie des Sayans occidentaux (Sibérie du sud) Anthropologie Vol. 98 Issue 2-3: 472-485.

Vassioukovitch, O., Orsini, M., Paparini, A., Gianfranceschi, G., Cattarini, O., Di Michele, P., Montuori, E., Vanini, G. C. \& Romano Spica, V. (2005). Detection of metazoan species as a public health issue: simple methods for the validation of food safety and quality Biotechnol Annu Rev Vol. 11 Issue: 335354.

Vuissoz, A., Worobey, M., Odegaard, N., Bunce, M., Machado, C. A., Lynnerup, N., Peacock, E. E. \&t Gilbert, M. T. P. (2007). The survival of PCR-amplifiable DNA in cow leather Journal of Archaeological Science Vol. 34 Issue 5: 823-829.

Wan, Q. H. Et Fang, S. G. (2003). Application of species-specific polymerase chain reaction in the forensic identification of tiger species Forensic Sci Int Vol. 131 Issue 1: 75-78.

Wan, X. F., Ren, T., Luo, K. J., Liao, M., Zhang, G. H., Chen, J. D., Cao, W. S., Li, Y., Jin, N. Y., Xu, D. \& Xin, C. A. (2005). Genetic characterization of H5N1 avian influenza viruses isolated in southern China during the 2003-04 avian influenza outbreaks Arch Virol Vol. 150 Issue 6: 1257-1266.

Wetton, J. H., Tsang, C. S., Roney, C. A. \& Spriggs, A. C. (2004). An extremely sensitive species-specific ARMs PCR test for the presence of tiger bone DNA Forensic Sci Int Vol. 140 Issue 1: 139-145.

Wilson, I. G. (1997). Inhibition and facilitation of nucleic acid amplification Appl Environ Microbiol Vol. 63 Issue 10: 37413751.

Woolfe, M. Et Primrose, S. (2004). Food forensics: using DNA technology to combat misdescription and fraud Trends Biotechnol Vol. 22 Issue 5: 222-226. 